\title{
Pemetaan Kebutuhan Pengembangan Bahan Ajar Digital
}

\section{Mapping of Digital Teaching Materials Development Needs}

\author{
Ismail Saleh Nasution ${ }^{13}{ }^{*}$, Eko Febri Syahputera Siregar11) \& Achmad Yuhdi2) \\ 1)Program Stud Pendidikan Guru Sekolah Dasar, Fakultas Keguruan dan Ilmu Pendidikan, \\ Universitas Muhammadiyah Sumatera Utara, Indonesia \\ 2) Program Studi Pendidikan Bahasa dan Sastra Indonesia, Universitas negeri Medan, \\ Indonesia
}

Diterima: 27 Juli 2020; Direview: 28 Agustus 2020; Disetujui: 14 Oktober 2020

\begin{abstract}
*Coresponding Email: ismailsalehnst@umsu.ac.id
Abstrak

Penelitian ini bermaksud melakukan pemetaan kebutuhan civitas akademika Prodi PGSD FKIP UMSU terhadap pengembangan bahan ajar digital yang dapat diakses mahasiswa setiap saat karena terintegrasi dengan android. Penelitian ini bagian dari penelitian pengembangan (R \& D). Jenis Penelitian ini adalah penelitian expo facto dimana peneliti melakukan pengumpulkan data secara langsung kepada responden melalui instrument pengumpulan data. Proses pengumpulan data merupakan tahapan dalam penelitian yang sangat penting. Data yang akan dikumpulkan nantinya akan digunakan untuk menguji hipotesis yang diajukan dalam penelitian dimana Data diperoleh melalui wawancara, angket, dan observasi. Teknik analisis data dilakukan dengan cara deskriptif kuantitatif. Hasil penelitian menunjukkan bahwa terdapat trend yang positif terhadap kebutuhan pengembangan bahan ajar berbasis digital di Prodi PGSD FKIP UMSU. Selama ini belum terdapat satu pun bahan ajar yang dikemas oleh dosen dalam bentuk digital di Prodi tersebut. Hasil angket kepada mahasiswa menunjukkan 90\% mahasiswa membutuhkan bahan ajar yang dapat diakses mereka pada saat kapan dan dimana saja mereka berada.
\end{abstract}

Kata Kunci: Bahan Ajar; Digital; Analisis Kebutuhan

\begin{abstract}
This study intends to map the needs of the PGSD FKIP UMSU academic community on the development of digital teaching materials that can be accessed by students at any time because they are integrated with Android. This research is part of the research development (R\&D). This type of research is an expo facto research where the researcher collects data directly from the respondent through a data collection instrument. The data collection process is a very important stage in research. The data to be collected will later be used to test the hypotheses proposed in the study where the data is obtained through interviews, questionnaires, and observations. The data analysis technique was done by using quantitative descriptive method. The results showed that there was a positive trend towards the need for digital-based teaching materials development in PGSD FKIP UMSU Study Program. So far, there has not been a single teaching material packaged by lecturers in digital form in the study program. The results of a questionnaire to students showed that $90 \%$ of students needed teaching materials that could be accessed by them at any time and wherever they were.
\end{abstract}

Keywords: Teaching Materials; Digital; Needs Analysis.

How to Cite: Nasution, I.S., Siregar, E.F.S., \& Yuhdi, A., (2020). Pemetaan Kebutuhan Pengembangan Bahan Ajar Digital,. Journal of Education, Humaniora and Social Sciences (JEHSS). 3 (2): 317-324. 


\section{PENDAHULUAN}

Era teknologi digital mulai merambah kepada semua sektor kehidupan, tak terk terkecuali pada dunia pendidikan, khususnya pendidikan tinggi. Aktivitas tridarma perguruan tinggi harus mengintegrasikan teknologi digital dalam proses dan publikasinya. Yuhdi (2018) menegaskan bahwa pembelajaran harus didesain seupaya mungkin secara daring dan mampu membuat komunikasi dosen dan mahasiswa dapat terjalin pada saat kapanpun.

Dalam hal pelaksanaan pembelajaran, khususnya kegiatan dosen dalam mengembangkan bahan ajar mata kuliah, si dosen pengampu mata kuliah harus mampu memastikan bahan ajar yang disusunnya dapat menjangkau si mahasiswa setiap saat. Hal ini menginngat pekerjaan membuat bahan ajar memiliki kontribusi yang sangat besar bagi keberhasilan proses pembelajaran yang dilakukan. Dengan menyadari hal ini, kita tidak lagi meremehkan dan mengesampingkan pembuatan bahan ajar. Akan tetapi, kita benar-benar dapat lebih serius menekuni dan mengerjakan pembuatan bahan ajar dengan penuh rasa tanggung jawab dan dedikasi yang tinggi.

Dosen merupakan orang yang tepat untuk melakukan kegiatan pengembangan bahan ajar. Hal tersebut dikarenakan seorang dosen sebagai pengampu mata kuliah dianggap mengetahui dengan pasti apa yang harus diajarkan dan apa yang harus dikuasai oleh mahasiswa setelah mengikuti perkuliahan. Sebagai seorang dosen dan sekaligus pengembang bahan ajar merupakan orang yang bertanggungjawab dalam pengaturan informasi dan lingkungan untuk keperluan penemuan ilmu pengetahuan mahasiswa. Untuk dapat mengembangkan bahan ajar dengan baik dan benar, seorang dosen perlu mempunyai beberapa pengetahuan dan ketrampilan antara lain, mengetahui arti bahan ajar, jenis bahan ajar dalam pembelajaran, beberapa faktor yang perlu dipertimbangkan dalam pengembangan bahan ajar, proedur pengembangan bahan ajar, penyusunan bahan ajar dan penerapan dalam proses pembelajaran.

Secara umum permasalahan akademik yang dihadapi mahasiswa dalam pembelajaran dapat dirinci: a) kurang menguasai cara belajar mandiri, b) kurang berhasil mencerna bahan perkuliahan dan materi literatur wajib, c) kesukaran mengatur antara waktu belajar dan aktivitas lainnya, d) kesukaran memperoleh buku sumber dan sumber belajar lain, e) kesukaran dalam menyelesaikan tugas-tugas; membuat laporan, makalah, resume, dan lain-lain, f) kesukaran dalam mempelajari buku-buku dalam bahasa asing (bahasa inggris), g) adanya kebiasaan belajar yang tidak tepat, dan h) rendahnya rasa ingin tahu (kurang minat dalam membaca).

Berdasarkan permasalahan yang dihadapi dosen terkait dengan beberapa faktor yang menyebabkan kesulitan belajar bagi mahasiswa, dapat diidentifikasi pokok permasalahannya, yakni terkait ketersediaan bahan ajar dan minat mahasiswa dalam mencari bahan bacaan sehingga menimbulkan penyerapan pemahaman materi oleh mahasiswa menjadi rendah. Dalam ha ini, dosen dapat memberikan jalan keluar terhadap masalah ini dengan menyusun bahan ajar yang dibutuhkan mahasiswa terkait mata kuliah yang diampu dosen itu.

Pengembangan bahan ajar oleh dosen juga dapat dijadikan sebagai rujukan ukuran profesionalisme. Hal tersebut mengacu kepada Penilaian Angka Kredit Jabatan Fugsional dan Pangkat Dosen. Dalam penelilaian Angka Kredit tersebut pengembangan inovatif dari materi substansial pengajaran berupa buku, modul, diktat, modul petunjuk, model, alat bantu dan sebagainya menjadi salah satu butir item penilaian yang harus dipenuhi oleh dosen.

Pengertian buku ajar di perguruan tinggi, secara luas merupakan jenis buku yang diperuntukkan bagi mahasiswa sebagai bekal pengetahuan dasar dan digunakan sebagai sarana belajar serta dipakai untuk menyertai proses pembelajaran. Di beberapa negara, jenis buku ini disebut sebagai textbook, tapi alih bahasa menjadi buku teks tidak cocok untuk menamai buku ini. Sesuai dengan jenis penggunaannya, istilah buku ajar lebih tepat dipakai sebagai padanan istilah text book dalam pembelajaran.

Perkembangan teknologi informasi dan komunikasi telah membawa perubahan yang sangat besar bagi kemajuan dunia pendidikan. Seiring dengan perkembangan tersebut bahan ajar yang disusun dosen perlu diintegrasikan dengan kemajuan teknologi. Bentuk dari 
perkembangan teknologi informasi yang diterapkan di dunia pendidikan terkait bahan ajar adalah bentuk digital bahan ajar berbasis aplikasi sistem operasi android. Pembelajaran ini termasuk dalam pembelajaran berbasis web/e-Learning. Pembelajaran berbasis internet/eLearning merupakan sebuah inovasi yang mempunyai kontribusi sangat besar terhadap perubahan proses pembelajaran, dimana proses belajar tidak lagi hanya mendengarkan uraian materi dari dosen tetapi mahasiswa juga melakukan aktivitas lain seperti mengamati, melakukan, mendemonstrasikan dan lain-lain.

Ratiyani (2014) Efektivitas pembelajaran melalui kegiatan pengembangan bahan ajar digital sangat berdampak pada aktivitas belajar. Melalui penelitian yang dilakukan Ratiyani tersebut, peningkatan aktivitas belajar terjadi pada proses pembelajaran yang ia lakukan. Peningkatan aktivitas belajar setelah menggunakan bahan ajar digital dengan aplikasi model pembelajaran siklus $5 \mathrm{E}$ (Learning cycle $5 \mathrm{E}$ ) yaitu sebesar $71,18 \%$ pada pertemuan pertama dan $79,51 \%$ pada pertemuan kedua.

Bahan ajar adalah seperangkat sarana atau alat pembelajaran yang berisikan materi pembelajaran, metode, batasan-batasan, dan cara mengevaluasi yang didesain secara sistematis dan menarik dalam rangka mencapai tujuan yang diharapkan, yaitu mencapai kompetensi atau subkompetensi dengan segala kompleksitasnya, sedangkan menurut Lestari (2013) bahan ajar haruslah dirancang dan ditulis dengan kaidah intruksional karena akan digunakan oleh guru untuk membantu dan menunjang proses pembelajaran. Bahan atau materi pembelajaran pada dasarnya adalah "isi" dari kurikulum, yakni berupa mata pelajaran atau bidang studi dengan topik/subtopik dan rinciannya (Ruhimat 2011).

Bahan ajar disusun dengan melihat berbagai macam tujuan yang ingin dicapai didalam kurikulum yang sedang digunakan yang selanjutnya terealisasikan melalui pembelajaran didalam kelas. Menurut Majid (2005), bahan ajar disusun dengan memiliki beberapa tujuan. Adapun tujuan-tujuan tersebut adalah sebagai berikut: 1.) Membantu mahasiswa dalam mempelajari sesuatu. 2.) Menyediakan berbagai jenis pilihan bahan ajar. 3.) Memudahkan guru dalam melaksanakan pembelajaran. 4.) Agar kegiatan pembelajaran menjadi menarik.

Ada beragam bentuk buku, baik yang digunakan untuk sekolah maupun perguruan tinggi, contohnya buku referensi, modul ajar, buku praktikum, bahan ajar, dan buku teks pelajaran. Jenis-jenis buku tersebut tentunya digunakan untuk mempermudah peserta didik untuk memahami materi ajar yang ada di dalamnya. Menurut Lestari (2008), sesuai dengan penulisan yang dikeluarkan oleh Direktorat Jenderal Pendidikan Dasar dan Menengah Departemen Pendidikan Nasional Tahun 2003 bahan ajar memiliki beberapa karakteristik, yaitu self instructional, self contained, stand alone, adaptive, dan user friendly.

Bahan ajar disusun sesuai dengan kaidah-kaidah yang telah ditentukan, agar nantinya bahan ajar yang disusun dapat menjadi bahan ajar yang tepat guna. Proses penyusunan materi pembelajaran dalam penulisan bahan ajar, harus disusun secara sistematis sehingga bahan ajar tersebut dapat menambah pengetahuan dan kompetensi peserta didik secara baik dan efektif. Penulisan bahan ajar merupakan proses penyusunan materi pembelajaran yang dikemas secara sistematis sehingga siap dipelajari oleh peserta didik untuk mencapai kompetensi atau sub kompetensi. Penyusunan bahan ajar mengacu pada kompetensi yang terdapat dalam Rencana Kegiatan Belajar-Mengajar, atau garis- garis besar program pendidikan dan pelatihan, atau unit kompetensi yang dibutuhkan di dunia kerja yang telah dikembangkan.

Setiadi (2018) dalam penelitiannya menjelaskan bahwa langkah-langkah pembuatan media pembelajaran dalam bentuk aplikasi android dapat ditempuh beberapa langkah, yaitu: 1) penyusunan media/flowchart, 2) pembuatan aplikasi dengan menggunakan softwere adobe animate CC, 3) mempublish ke dalam bentuk apk yang nantinya dapat diinstal di smartphone android, dan 4) Tahap pengujian pada smartphone dapat dijalan menggunakan proses debugging pada perangkat smartphone, pada penelitian ini tahap pengujian menggunakan smartphone Samsung Galaxy J5 dengan spesifikasi CPU: QuadCore, $1.2 \mathrm{GHz}$ Display: Super AMOLED, 720 x 1280 (HD), Camera Resolution: CMOS 13.0 MP, Versi Android 4.4 Kitkat. 
Sistem digital yang popular ditengah masyarakat saat ini adalah android. Android merupakan salah satu platform system yang terbuka yang memungkinkan kita bisa membuat aplikasi sendiri sebagai developer di google playstore. Nah, sebagai guru yang kekinian dan melek teknologi tidak ada salahnya untuk mencoba membuat aplikasi android untuk dapat digunakan sebagai salah satu media pembelajaran di sekolah sebagai tugas terstruktur ataupun tugas di rumah. Salah satu aplikasi itu adalah aplikasi kuis, di mana di dalamnya ada materi dan soal yang bisa dikerjakan mahasiswa dengan menginstall aplikasi di gadgetnya terlebih dahulu kemudian dikerjakan di gadgetnya dan langsung tahu hasil atau skor yang diperoleh. Tujuannya adalah mahasiswa bisa lebih senang belajar karena dengan aplikasi kuis mahasiswa menjadi tahu materi yang belum bisa dikuasai.

\section{METODE PENELITIAN}

Pendekatan penelitian ini merupakan bagian dari penelitian pengembangan. Peneltian dan pengembangan adalah metode penelitian yang digunakan untuk menghasilkan produk tertentu, dan menguji keefektifan produk tersebut. Untuk dapat menghasilkan produk tertentu digunakan penelitian yang bersifat analisis kebutuhan dan untuk menguji keefektifan produk tersebut supaya berfungsi di masyarakat luas, maka diperlukan penelitian untuk dapat menguji keefektifan produk tersebut (Sugiyono, 2009).

Jenis Penelitian ini adalah penelitian expo facto dimana peneliti melakukan pengumpulkan data secara langsung kepada responden melalui instrument pengumpulan data. Proses pengumpulan data merupakan tahapan dalam penelitian yang sangat penting. Data yang akan dikumpulkan nantinya akan digunakan untuk menguji hipotesis yang diajukan dalam penelitian dimana Data diperoleh melalui wawancara, angket, dan observasi. Teknik analisis data dilakukan dengan cara deskriptif kuantitatif. Adapun sampel dalam penelitian ini adalah mahasiswa Prodi PGSD UMSU dan dosen yang mengajar di Prodi tersebut. Sampel dipilih menggunakan metode pengambilan sampel secara purposive sampling.

\section{HASIL DAN PEMBAHASAN}

Berdasarkan hasil angket yang diberikan kepada dosen yang mengajar di Prodi PGSD FKIP UMSU, sebagian besar dosen membutuhkan bahan ajar digital agar memudahkan mahasiswa dalam pencapaian materi pembelajaran. Terdapat lima pertanyaan yang dijawab oleh para dosen untuk menjaring data tingkat kebutuhan dosen terhadap pengembangan bahan ajar digital di Prodi FKIP UMSU. Kelima pertanyaan itu adalah:

1) Untuk mencapai tujuan pembelajaran Daring (Online) membutuhkan bahan ajar digital yang efektif efisien,

2) Untuk meningkatkan nilai akreditasi program studi PGSD UMSU, dosen harus memiliki kemampuan yang baik dalam bidang pendidikan dan pengajaran khususnya dalam inovasi teknologi informasi digital,

3) Saya menerapkan pembelajaran daring pada masa Pandemi Covid 19 secara maksimal,

4) Saya memberikan referensi bahan ajar berbentuk aplikasi yang adapat diakses dari Android secara offline,

5) Saya menyakini mampu mengembangkan bahan ajar digital.

Jumlah responden dosen yang mengisi instrument penelitian ini adalah 7 orang dosen yang mengajar di Prodi PGSD FKIP UMSU. Secara lengkap, isian dari tiap instrument tersebut di atas, dapat dijelaskan melalui bagan berikut.

\section{a. Bahan Ajar Digital untuk Pencapaian Tujuan Pembelajaran Daring}

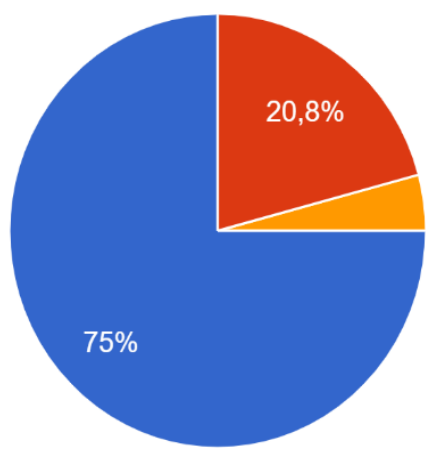




\section{Gambar 1.}

Diagram Isian instrumen kebutuhan bahan ajar digital dalam pembelajaran daring

Berdasarkan data yang ditunjukkan pada diagram di atas, diketahui bahwa semua responden menyetujui pernyataan bahwasanya dalam melaksanakan pembelajaran daring yang efektif dan efisien, dibutuhkan sebuah bahan ajar yang berbentuk digital. Secara rinci terdapat $75 \%$ responden (7 orang dosen dan 11 mahasiswa) menjawab sangat setuju, sedangkan 20,8\% ( 2 orang dosen dan 3 mahasiswa) menjawab setuju terhadap pernyataan yang disebutkan dalam instrumen nomor 1. Pada butir pertanyaan ini terdapat 1 mahasiswa menjawab netral.

\section{b. Inovasi dalam Pembelajaran Meningkatkan Akreditasi Prodi}

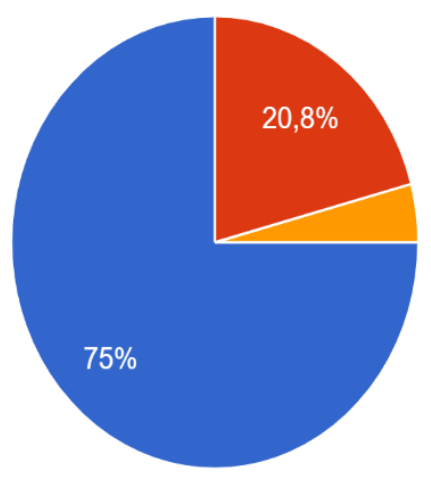

Sangat Setuju

Setuju

Netral

Tidak Setujua

Sangat Tidak Setuju

Gambar 2.

Diagram Isian instrumen atas pernyataan "Inovasi dalam Pembelajaran Meningkatkan Akreditasi

Berdasarkan data yang ditunjukkan pada diagram di atas, diketahui bahwa semua responden menyetujui pernyataan bahwasanya untuk meningkatkan nilai akreditasi Program Studi PGSD FKIP UMSU, dosen harus memiliki kemampuan yang baik dalam bidang pendidikan dan pengajaran, khususnya dalam inovasi teknologi informasi digital. Secara rinci terdapat $75 \%$ responden ( 7 orang dosen dan 11 mahasiswa) menjawab sangat setuju, sedangkan $20,8 \%$ (2 orang dosen dan 3 mahasiswa) menjawab setuju terhadap pernyataan yang disebutkan dalam instrumen nomor 2, yakni untuk meningkatkan nilai akreditasi program studi PGSD UMSU, dosen harus memiliki kemampuan yang baik dalam bidang pendidikan dan pengajaran, khususnyadalam inovasi teknologi informasi digital. Pada butir pertanyaan ini terdapat 1 mahasiswa menjawab netral.

\section{c. Dosen Menerapkan Pembelajaran Daring dengan Maksimal saat Pandemi}




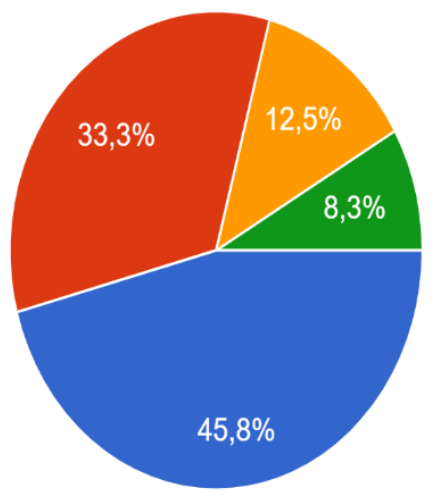

Sangat Setuju

Setuju

Netral

Tidak Setuju

Sangat Tidak Setuju

Gambar 3.

Diagram Isian instrumen Dosen Menerapkan Pembelajaran Daring Saat Pandemi

Berdasarkan data yang ditunjukkan pada diagram di atas, diketahui bahwa semua responden menyetujui pernyataan bahwasanya dosen telah menerapkan pembelajaran daring dengan maksimal saat situasi pandemi covid 19. Secara rinci terdapat $45 \%$ responden (6 orang dosen dan 5 orang mahasiswa) menjawab sangat setuju, sedangkan 33,3\% (3 orang dosen dan 5 orang mahasiswa) menjawab bahwa mereka telah menerapkan pembelajaran daring secara maksimal kepada mahasiswa dan mahasiswa juga mengatakan hal yang sama. Sebanyak 12,5\% (3 orang mahasiswa) tidak memberikan pernyataan apapun/netral terhadap pertanyaan butir nomor 3 ini. Kemudian, 8,3\% (2 orang mahasiswa) memberikan komentar tidak setuju terdapat pernyataan yang diberikan. Setelah dilakukan wawancara lebih lanjut, diketahui bahwa tidak satupun dosen memiliki bahan ajar dalam bentuk aplikasi yang terintegrasi dalam sistem operasi android. Pembelajaran daring yang dilakukan selama ini, secara umum adalah penyajian materi dan mmenyampaikan tugas kepada mahasiswa melalui google classrom dan wa group saja.

d. Dosen Memberikan Referensi Bahan Ajar Berbentuk Aplikasi yang Dapat Diakses Dari Android Secara Offline

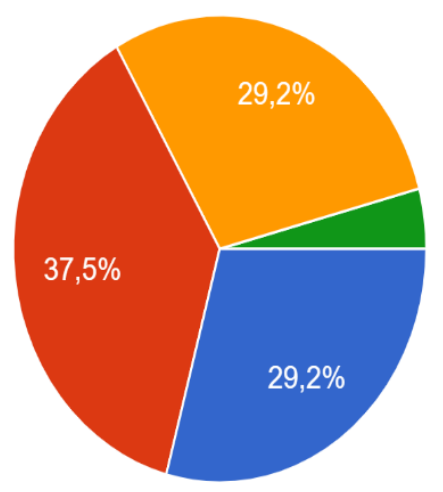

\author{
Sangat Setuju \\ Setuju \\ Netral \\ Tidak Setuju \\ Sangat Tidak Setuju
}

Gambar 4.

Diagram Isian instrumen atas pernyataan "Dosen memberikan bahan ajar dalam bentuk digital"

Berdasarkan data yang ditunjukkan pada diagram di atas, diketahui bahwa terdapat beragam jawaban yang diberikan responden terhadap pernyataan butir nomor 4 ini. Secara rinci terdapat 29,2\% responden (4 orang dosen dan 2 orang mahasiswa) menjawab sangat setuju, artinya responden memberikan referensi bahan ajar yang dapat diakses secara offline melalui 
android, sedangkan 37,5\% (2 orang dosen dan 7 orang mahasiswa) menjawab setuju. Sebanyak $29,5 \%$ ( 2 orang dosen dan 5 orang mahasiswa) tidak memberikan pernyataan apapun/netral terhadap pertanyaan butir nomor 4 ini.

\title{
e. Kemampuan Dosen Mengembangkan Bahan Ajar Digital
}

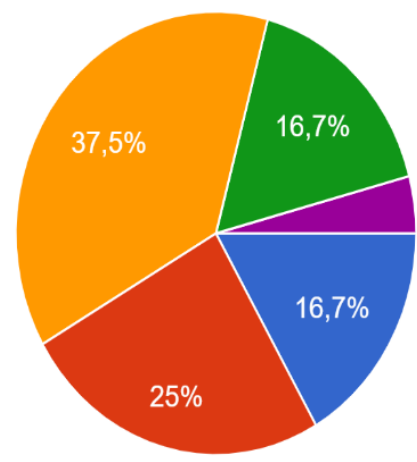

\author{
Sangat Setuju \\ Setuju \\ Netral \\ Tidak Setuju \\ Sangat Tidak Setuju
}

Gambar 5.

Diagram Isian instrumen atas pernyataan "Kemampuan dosen mengembangkan bahan ajar digital"

Berdasarkan data yang ditunjukkan pada diagram di atas, diketahui bahwa terdapat beragam jawaban yang diberikan responden terhadap pernyataan butir nomor 5 ini. Secara rinci terdapat $16,7 \%$ responden ( 5 orang dosen dan 2 orang mahasiswa) menjawab sangat setuju, artinya responden itu meyakini bahwa dirinya (bagi dosen) dan (dosennya, bagi mahasiswa) mampu mengembangkan bahan ajar digital dalam bentuk aplikasi, sedangkan 37,5\% (2 orang dosen dan 7 orang mahasiswa) menjawab setuju (mampu mengembangkan bahan ajar digital). Sebanyak 37,5\% (2 orang dosen dan 5 orang mahasiswa) tidak memberikan pernyataan apapun/netral terhadap pertanyaan butir nomor 4 ini. Kemudian, 16,7\% (1 orang mahasiswa) memberikan komentar tidak setuju terdapat pernyataan yang diberikan atau tidak yakin bahwa dosen yang memberikan perkuliahan kepada mereka mampu untuk mengembangkan bahan ajar dalam bentuk digital.

\section{SIMPULAN}

Hasil penelitian menunjukkan bahwa terdapat trend yang positif terhadap kebutuhan pengembangan bahan ajar berbasis digital di Prodi PGSD FKIP UMSU. Selama ini belum terdapat satu pun bahan ajar yang dikemas oleh dosen dalam bentuk digital di Prodi tersebut. Hasil angket kepada mahasiswa menunjukkan 90\% mahasiswa membutuhkan bahan ajar yang dapat diakses mereka pada saat kapan dan dimana saja mereka berada. Sementara itu, dosen juga menginginkan dibentuknya tim dosen bidang keahlian untuk bersama dilatih mengembangkan bahan ajar berbasis digital yang mampu membuat pembelajaran menjadi lebih efektif dan efesien.

\section{DAFTAR PUSTAKA}

Basori. (2013). Pemanfaatan Social Learning Network Schoology dalam Membantu Perkuliahan Teori Bodi Otomotif di Prodi PTM JPTK FKIP UNS. JIPTEK. No. 21. Surakarta: UNS Press.

Lestari. 2013. Pengembangan Bahan Ajar Berbasis Kompetensi. Padang: Akademia Permata

Majid, A. 2005. Perencanaan Pembelajaran Mengembangkan Standar Kompetensi Guru. Bandung: Rosdakarya.

Ratiyani, I, dkk. 2014. Pengembangan Bahan Ajar Digital dan Aplikasinya dalam Model Siklus Pembelajaran 5E

(Learning Cycle 5E) Terhadap Aktivitas dan Hasil Belajar. PANCARAN PENDIDIKAN. Vol 3 No 1 p. 79-88.

Dari: https://jurnal.unej.ac.id/index.php/pancaran/article/view/725

Rusman. (2012). Belajar dan Pembelajaran Berbasis Komputer. Bandung: Alfabeta. 
Ruhimat, T. Dkk, (2011). Kurikulum dan Pembelajaran. Jakarta. PT Raja Grafindo Persada.

Sugiyono. (2015). Metode Penelitian Pendidikan (Pendekatan Kuantitatif, Kualitatif dan R\&D). Penerbit CV. Alfabeta: Bandung.

Setiadi, A, dkk. (2018). Pengembangan Aplikasi Android untuk Pembelajaran Pneumatik. Jurnal Pendidikan Vokasional Teknik Elektronika. Vol. I No.1, April 2018|. Hal 1-5. Dari: journal.unj.ac.id/unj/index.php/ jvote/article

Yuhdi, A, dan Amalia, N. (2018). Desain Media Pembelajaran Berbasis Daring Memanfaatkan Portal Schoo-logy pada Pembelajaran Apresiasi Sastra. Basastra: Jurnal Kajian Bahasa dan Sastra Indonesia. 7/(1)/2018. 1422. DOI: https://doi.org/10.24114/bss.v7i1.9320 